\title{
OPPIVA ORGANISAATIO - TYHJÄ KÄSITE VAI KEHITTÄMISEN VÄLINE?
}

\author{
Oppimisen tutkimuksessa käyttöön otettu oppivan organisaation käsite \\ on vakiintunut hyvin myös arkikäyttöön. Termi esiintyy myös yhä useam- \\ min hallinnollisessa kielessä mm. sovellettaessa uutta koululakia ja \\ pohdittaessa ihmisten johtamisen taitojen yhteyttä teollisuusyritysten \\ menestymiseen. Käsitettä saatetaan viljellä kielenkäytössä sisäistämättä \\ sen ideaa ja kysymättä, mitä ja miten organisaatio oppii. Artikkelin \\ näkökulmana on koulutusorganisaatio.
}

\section{TIINA SOINI, MAIJALIISARAUSTE-VON WRIGHT \& KIRSI PYHÄLTÖ}

I hmiskunnan historiassa olemme tilanteessa, jossa voi aiheellisesti olla huolissaan lajimme selviytymisestä jopa lähitulevaisuudessa. Ihmisen oppimisen valmiuksiin suhtaudutaan kuitenkin hyvin optimistisesti. Koulutus on keskeisessä asemassa esimerkiksi sosiaalista tasa-arvoisuutta ja kestävää kehitystä koskevissa tulevaisuuden strategioissa. Tästä näkökulmasta oppivien organisaatioiden ja oppimisyhteiskunnan rakentaminen on hyvin oleellista huomattavasti "tehokkuuden maksimointia" laajemmassa mielessä. Tulevaisuudessa ei riitä se, että tuotantolaitokset toimivat taloudellisesti mahdollisimman tehokkaasti. Yhteiskuntarauhan säilyttämiseksi ja ekokatastrofien ehkäisemikseksi tarvitaan myös "uudenlaista ajattelua tuottavia" organisaatioita, joissa ihmiset jaksavat ja haluavat toimia. Organisaatioiden tutkijat ovatkin todenneet, että kaikkien organisaatioiden olisi oman selviämisensä vuoksi pyrittävä kehittymään oppiviksi organisaatioiksi (mm. Senge, 1990; Pedler et al., 1991).

Puhe tietoyhteiskunnasta on alkanut muuttua puheeksi oppimisyhteiskunnasta (mm. Euroopan komission valkoinen kirja koulutuksesta 1996). Koulutusorganisaatiot peruskoulusta lähtien olisivat luontevia tahoja toimimaan tämän kehityksen kärjessä. Peruskoulu koskettaa miltei jokaista yhteiskunnan jäsentä ja sen jälkeenkin suurin osa ihmisistä viettää elämänsä aikana yhä enemmän aikaa nimenomaan koulutusorganisaatioissa. Kehitys kohti oppimisen yhteiskuntaa edellyttää kuitenkin koulujen muuttumista oppiviksi organisaatioiksi, oppimisyhteisöiksi. Tällöin pe- rinteisen suoriutumisen ja suorittamisen sijaan keskeiseksi opettajan ja oppilaan toimintastrategiaksi muodostuisi jaettu oppiminen. Näin pystyttäisiin avaamaan ja prosessoimaan asioita, jotka sekä opettajat että oppilaat kokevat ongelmiksi kiireisessä koulutodellisuudessa. Hyväksi tulosvastuullisuudeksi tulkitun jatkuvan, kiireisen muutoksen sijaan voitaisiin tällöin korostaa oppimisen kannalta keskeisiä asioita, kuten pysähtymistä ja reflektointia. Näin myös traditionaalisen, opettajan oikeuksia lisäävän ja yhteistä oppimisympäristöä rajoittavan koulukurin sijasta voitaisiin herätä vaatimaan ja luomaan koulun toimintakulttuuriin sekä vuorovaikutukseltaan että informatiivisuudeltaan vaihtelevia tilanteita. Innovaatiivisuus koulussa voisi merkitä halua etsiä yhdessä uusia toiminnan ja ajattelun ulottuvuuksia ja ongelmaratkaisun mahdollisuuksia.

Koulut ovat yhä enemmän kilpailuasemassa keskenään. Koulujen vertailun kriteereissä painottuvat kuitenkin lähinnä määrälliset seikat. Tällöin luontevaa onkin, että paremmuudesta kilpaillaan oppilaskeskiarvoilla ja lisäämällä koulun toimintaan jotain uutta ja jännittävää, painopisteitä ja projekteja. Samaan aikaan kuitenkin sekä opettajat että oppilaat toivovat kouluun selkeyttä ja aikaa ajatella, "vähemmän mutta parempaa". Arvioinnin kriteereitä olisikin ehkä syytä tarkistaa oppimisen mahdollistamisen näkökulmasta. Mitä todennnäköisemmin yksittäinen koulu, jonka tavoite on toimia hyvänä - kiireettömänä, turvallisena ja yhteisöllisenä - oppimisyhteisönä kaikille jäsenilleen, pärjäisi hyvin myös kilpailussa 
oppilaista. Toisin sanoen oppimisyhteiskuntaa ja oppivaa organisaatiota täytyisi "elää todeksi" kaikilla koulutustasoilla ja elämän aloilla.

Onko oppivan organisaation käsitteestä välineeksi tähän kehittämistyöhön? Vaikka käsitteen käyttö on yleistynyt, yhtenäistä oppivan organisaation teoreettista viitekehystä ei kuitenkaan ole näkyvissä. Lähtökohdat organisaation oppimisen tutkimukseen vaihtelevat usein tutkijan oman taustan mukaan (ks. Moilanen, 1996). Kaikkien uusien käsitteiden kannalta on ongelmallista, jos ne rutinoituvat arkikielen käyttöön vaiheessa, jossa niiden tieteellinenkään määrittely ei ole täsmentynyt. Tällöin voidaan puhua esimerkiksi "käsitteen tyhjentymisestä" tai "vieraantumisesta". Edellisessä tapauksessa käsite hajoaa jo ennenkuin se on käynyt läpi tieteellisen, kriittisen analyysin. Jälkimmäisessä tapauksessa taas uuden käsitteen merkityssisältö jää alunperin toisarvoiseen asemaan. Uusi ajatus kytketään tällöin termin muodossa suoraan osaksi vanhoja käytänteitä. Tällöin se yleensä kanavoituu irrallisiksi menetelmiksi ja metodeiksi, joiden perustelut (esimerkiksi ihmiskäsitys) jäävät epäselviksi. Koska menetelmien käyttöä tai käyttämättä jättämistä ei näin ollen pystytä perustelemaan, päädytään helposti väittelyyn oikeasta ja väärästä. Näin termi saa itse asiassa lähinnä normatiivisaffektiivisen latauksen.

Tässä artikkelissa pohdimme oppimista yhteisön ja organisaation kontekstissa. Tavoitteenamme on avata ja jäsentää oppivan organisaation käsitettä ja siihen liittyvää termistöä. Artikkelissa pohdimme käsitteen mahdollisuuksia toimia todellisuutta jäsentävänä ja toimintaa ja ajattelua ohjaavana kehittämisen välineenä. Tarkastelujemme reflektiivisenä välineenä on toiminut havaintomme koulun todellisuudessa (ks. tarkemmin Koulun eksperttiys. Tutkimus yhtenäisen peruskoulun toteutumisen ehdoista, Rauste-von Wright et al., 2003). ${ }^{1}$

\section{OPPIVAN ORGANISAATION KÄSITTEEN ONGELMALLISUUDESTA}

Oppiva organisaatio on hyvä osoitus käsitteestä, jonka sisältö tyydytään usein määrittelemään joukolla kuvauksia tai piirteitä, kuten avoin kommunikaatio, joustavuus, muutoksen johtaminen, jaettu visio jne. Käsitteen funktionaalinen puoli jää vähälle huomiolle ja hyvän käsitteen tärkein kriteeri, ajattelun ja kehittämisen välineenä toimiminen kärsii. Pelkkä oppivan organisaation terminologian käyttöönotto esimerkiksi erilaisiin strategiasuunnitelmiin on mahdollista ilman sen takana olevan idean käsitteellistä sisäistämistä, esimerkiksi kysymättä sen tarkemmin mitä ja miten organisaatio oppii.

Edellä esitetyn kaltaisia ongelmia liittyy myös oppivan organisaation käsitteeseen usein liitettäviin itsearvioinnin, oppimaan oppimisen ja elinikäisen oppimisen termeihin. Niitä käytetään nykyään runsaasti ikäänkuin käsitteiden merkitykset olisivat itsestään selvästi ongelmattomia. Samalla kun näistä käsitteistä on tullut muoti-ilmiöitä, on myös kynnys niiden merkityssisältöjen kyseenalaistamiseen noussut kovin korkeaksi. Oppivan organisaation käsitteen osalta vaikuttaa siltä, että sen analysointi - silloin kun tällaista yritetään - perustuu organisaatioteorioiden näkökulmaan, oppimisprosessin problematiikan jäädessa kovin vähälle huomiolle. Perinteisissä organisaatioteorioissa oppiminen yleensä jää implisiittiseksi, usein mekanistiseksi itsestään selvyydeksi (esim. Resnick \& Williams Hall, 1998).

Pyrittäessä tutkimaan ilmiöitä, kuten organisaation oppimista, on kuitenkin määriteltävä tiettyjä kriteereitä tarkasteluille. Jotta ilmiö voitaisiin ottaa tarkasteluun oppimisen kannalta, on määriteltävä, miten oppiminen organisaation toiminnassa näkyy. Organisaatioiden kuvaamisen sijasta vaikuttaisi mielekkäältä pyrkiä löytämään organisaation oppimista sääteleviä - ja mielekkään toiminnan mahdollistavia ja myös estäviä tekijöitä, tunnettujen organisaatioteoreettikkojen Argyrisin ja Schönin (1978) sanoin: itseään vahvistavia, oppimista mahdollistavia tai estäviä prosesseja. Voitaisiin puhua myös erilaisista, laadukkaista ja vähemmän laadukkaista oppimisprosesseista. Asian tuominen oppimisprosessien tarkastelujen tasolle auttaa jo jäsentämään tarkemmin, mitä oppiva organisaatio lopulta voisi olla.

\section{OPPIMINEN JA ORGANISAATIO}

Aloitamme oppimisprosessin määrittelystä, koska oppimisen käsite on - näin väitämme - edelleen erittäin epämääräinen. Tämän jälkeen pohdimme organisaation oppimisen ehtoja siihen liittyvien termien kautta.

Oppiminen on sekä arkikielen että tieteenkielen sana. Ongelmallista onkin, ettei tutkimuksissa läheskään aina oteta tietoisesti kantaa siihen, 
mitä oppimisella ko. yhteydessä tarkoitetaan, esimerkiksi milloin oppimista käsitellään tietoisesti tieteellisenä käsitteenä. Näin ollen tarvitsemme edelleen konstruktivismin yleiskäsitettä määrittämään ihmis- ja oppimiskäsityksemme erottuvaksi esimerkiksi erilaisista mekanistisesti toiminnan ulkoiseen säätelyyn liittyvistä käsityksistä. Konstruktivismi on noussut yläkäsitteeksi varsin erilaisille suuntauksille, joita yhdistää lähinnä samankaltainen tiedonkäsitys (ks. esim. Tynjälä, 1999). Tarvitsemme siis konstruktivismin erittelyä käsitteellisten kriteerien pohjalta. Tässä artikkelissa lähestymme oppivaa organisaatiota pragmatistiskonstruktivistisesta viitekehyksestä (Rauste-von Wright et al., 2003, Pyhältö, 2003).

Oppimisen on hyvin keskeinen inhimillinen perusprosessi. Oppimista ei tapahdu vain silloin, kun opetetaan eli ns. formaalisissa prosesseissa, esimerkiksi koulussa, vaan kaikissa tilanteissa läpi ihmisen elämän. Se, mitä ihminen oppii, riippuu siitä, mihin kohdistuu hänen valikoiva tarkkaavaisuutensa ja miten hän tulkitsee havaintojaan (esim. Rauste-von Wright et al., 2003). Pragmatistiskonstruktivistinen oppimiskäsitys yhdistää sosiokonstruktivistisen ja kognitiivisen näkemyksen, jolloin yksilölliset ja sosiaaliset ulottuvuudet nivoutuvat oppimisen kokonaisprosessiksi (esim. Cobb, 1994; Greeno, 1997; Salomon, 1997; Cobb \& Bowers, 1999). Tästä näkökulmasta vuorovaikutus monilla eri tasoilla jäsentyy oppimisen ehdoksi ja keskeisimmäksi säätelijäksi. Oppiminen on vuorovaikutusprosessi ja ihmisen selviytymisen kannalta välttämätön toiminnan muutoksen ehto. Sen onnistuminen säätelee, ei vain yksilön, vaan myös pienyhteisön ja makroyhteisön selviytymistä. Ihmiskunnan historian myötä selviytymisprosessi on tullut yhä komplisoidummaksi samalla, kun ihmislaji on oppinut muokkaamaan ympäristöään esimerkiksi teknisin keksinnöin.

Oppiminen on perinteisesti nähty yksilötason toimintana. Menneenä vuosikymmenenä oppimisen tarkastelu on siirtynyt yhä enemmän ryhmien ja yhteisöjen tasolle. Ongelmana on, että usein esimerkiksi yhteistoiminnallinen tai yhteisöllinen oppiminen esitetään itseisarvoisesti laadukkaampana kuin yksilön toimintaan perustuva oppiminen (tähän ovat Suomessa kiinnittäneet huomiota mm. Rasku-Puttonen \& Eteläpelto, 1999). Ihmisen oppimisen ymmärtäminen sosiaalisena ja jatkuvana vuorovaikutusprosessina tarkoittaa kuitenkin käytännössä hyvin varioivia oppimis- ympäristöjä ja toimimista sekä yksin että yhdessä. Opimme jatkuvasti, mutta emme ole jatkuvassa sosiaalisessa kontaktissa. Myös yksin ollessamme ajattelumme voidaan toki ymmärtää sisäistyneenä vuoropuheluna. Jos yksilötason toiminnan osuus jätetään huomiotta oppimisen prosessissa, jäävät myös mahdollisuudet tarkastella inhimillistä toimintaa kokonaisvaltaisena ja systeemisesti organisoituneena vähäisiksi.

Pelkkä runsas sosiaalinen vuorovaikutus ei ole myöskään oppivan organisaation eikä toimivan pienryhmän tunnusmerkki, mutta oppimisen kriteerit täyttävä, laadukas vuorovaikutus voi sitä olla. Kun toiminnan tavoite on oppiminen, on tärkeää saada aikaan oppimisprosessin eri vaiheiden kannalta mielekästä (siis kriteerit täyttävää) vaihtelevaa vuorovaikutusta. Tämän on toiminnan ohjaamisen suuri haaste ja sitä voitaisiin pitää niin yritysten johtajien, opettajien kuin rehtorienkin osaamisen ytimenä. Tutkijat ovat jäsentäneet sosiaalista vuorovaikutusta oppimisen säätelijänä melko runsaasti. Vaikuttaa kuitenkin siltä, että organisaatioissa arjen

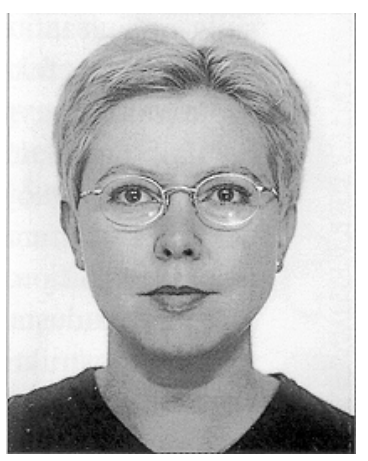

Tiina Soini

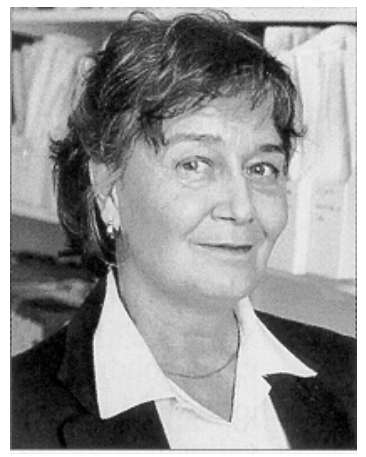

Maijaliisa Rauste -von Wright

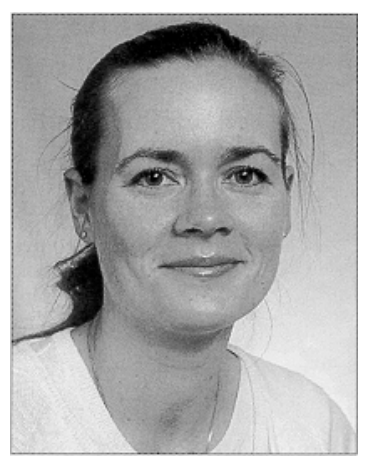

Kirsi Pyhältö sovelluksiin pyritään ilman riittävää keskustelua siitä, mistä on todella kysymys; miten kommunikaatiokulttuuri säätelee oppimista, mitä muuta kuin yhdessä toimimista yhteistoiminnallisuus tarkoittaa, millaista oppimista mahdollistaa pientyhmä("tiimi") -työskentely jne.? Organisaation oppimista ei voi suoraan johtaa yksilön oppimisesta, vaikka niistä on löydettävissä yhteisiä elementtejä. Ryhmä oppivia ihmisiä ei myöskään vielä tee oppivaa organisaatiota.

Oppivan organisaation määrittelyissä on yleensä pidetty keskeisenä toisaalta jaettua vi- 
siota organisaation suunnasta ja toisaalta organisaatiotason tukea yksilöiden oppimisprosesseille (esim. Argyris \& Schön 1978; Senge, 1990; Sarala \& Sarala, 1996; Moilanen, 1996; Nikkanen \& Lyytinen, 1996). Oppimisen tutkimuksen kannalta tarkasteltuna kyse on siis jaetusta tiedosta (shared cognition, esim. Resnick, 1991) ja organisaation laadusta oppimisympäristönä. Pragmatistisen konstruktivistismin näkökulmasta oppiva organisaatio määrittyy esimerkiksi seuraavasti:

Oppivan organisaation muodostaa yhteisö oppijoiksi itsensä kokevia yksilöitä, jotka tietoisesti luovat mielekkäitä oppimisympäristöjä itselleen ja muille yhteisesti konstruoidun toiminnan tavoitteen suunnassa.

Tämä määritelmä sisältää ajatuksen sekä oppimaan oppimisesta että itsearvioinnista. Jotta yksilöt organisaatiossa voivat kokea itsensä oppijoina, on itsearvioinnin ja oppimaan oppimisen valmiuksien täytynyt sisäistyä, ei vain ajattelun, vaan myös muun toiminnan strategiaksi. Seuraavassa pohdimme, miten nämä termit tulisi tulkita, jotta niitä on mahdollista käyttää kehittämisen välineinä.

\section{ORGANISAATION OPPIMAAN OPPIMINEN}

Oppivan organisaation tematiikka yhdistyy, kuten edellä todettiin, oppimaan oppimisen ja itsearvioinnin termeihin. Nämä puolestaan sisältävät ajatuksen elinikäisestä oppimisesta ja valmiudesta jatkuvaan oman toiminnan tarkasteluun ja muutokseen. Väärin ymmärrettyinä nämä käsitteet voivat aiheuttaa ahdistusta ja riittämättömyydentunteita organisaation toimijoissa. Käsittelemme tässä lyhyesti näihin käsitteisiin liittyviä arjen tulkintoja ja osittaisia väärinymmärryksiä koulutusorganisaatiossa.

\section{ITSEARVIOINTI}

Mielikuvat itsearvioinnista liittyvät, etenkin koulun diskurssissa, perinteiseen koulu- ja oppilasarviointiin. Tällöin on vaarana tulkita itsearviointi omien onnistuneiden tai epäonnistuneiden suoritusten kirjaamisena. Ja kulttuurisesti opittu strategia on usein juuri painottua epäonnistumisiin. Tämä johtaa pahimmillaan virheiden ja sitä kautta riskien välttämiseen. Hallinnon tasolla itsearviointi on usein tulkittu hyvin byrokraattisesti ja sen käytännön toteutus näkyy lähinnä erilaisten itsearviointilomakkeiden tulona kouluihin. Sekaannusta aiheuttaa myös saman käsitteen käyttö hyvin erilaisissa merkityksissä ja melko epäselviksi jäävät yhteydet käytännön ja periaatteiden välillä. Esimerkiksi perusopetuksen opetussuunnitelman perusteissa puhutaan itsearvioinnista keinona oman oppimisen ohjaamisen ja elinikäisen oppimisen valmiuksien oppimiseen. Tämä on siis uusimpaan oppimisen tutkimukseen perustuva tulkinta. Käytännön toteuksesta ei kuitenkaan todeta mitään. Toisaalta esimerkiksi kouluille tarjotut itsearviointilomakkeet ovat lähinnä asiakastyytyväisyyskyselyjen kaltaisia monivalintalomakkeita. Lomakkeet voivat toki toimia kartoituksena koulun tilasta (oppilaiden tyytyväisyydestä, ilmapiiristä ja fyysisistä tiloista), mutta oppimaan oppimista ne eivät sinällään tue. Koulutusorganisaatio voi luoda oman itsearviointikäytäntönsä, esimerkiksi muokata lomakkeita, joissa keskitytään enemmän juuri oppimisen tarkasteluun. Oppimaan oppimisen ja oppivan organisaation kannalta on kuitenkin ongelmallista, jos itsearviointi "suoritetaan" yksin yksityiskohtaisen lomakkeen avulla, jolloin sen reflektiivista ja yhteisöllistä työotetta tukeva vaikutus vähäiseksi.

Jos otamme oppivan organisaation käsitteen tosissamme ja alamme toteuttaa sitä modernin oppimisesta saadun tiedon mukaisesti, se aiheuttaa melko radikaaleja muutoksia koko organisaation toiminnassa. Hyvänä esimerkkinä voisi olla Rauste -von Wrightin (esim. 1997) ajatukset muutoksesta koulutusprosessin jäsentämisessä.

Perinteisesti ymmärretty koulutusprosessi etenee perättäisinä vaiheina:

\section{TAVOITE-TOTEUTUS -ARVIOINTI}

Koulutus modernisti ymmärrettynä reflektiivisena ja itseään korjaavana (johon kaiketi esimerkiksi itsearvioinnin tuominen kouluille pyrkii) prosessina voitaisiin kuvata kolmiona:

\section{TAVOITE}

\section{TOTEUTUS}

\section{ARVIOINTI}

Tämä sinänsä yksinkertaiselta vaikuttava muutos vaikuttaa hyvin moneen oppimista säätelevään tekijään. Yksi reflektiivisen mallin perusedellytyksistä - ja samalla ehkä radikaalein ero perinteiseen koulutusprosessiin sisältyy ajatukseen 
tavoitteen arvioinnista. Jotta tavoitetta voi arvioida, se on tiedettävä. Kolmiossa kuvattu koulutusprosessi pakottaa neuvottelemaan tavoitteesta prosessin alusta asti. Näin ollen se parhaimmillaan johdattaa kysymään, ovatko asetetut tavoitteet todella organisaatiossa sillä hetkellä aidosti heränneitä kysymyksiä.

Tämä vaikuttaa ainakin kahdella eri tasolla: Jotta organisaatio voisi arvioida oppimistavoitettaan, kaikilla organisaatiossa toimivilla tulisi olla käsitys siitä, mikä tavoite on. Ja jotta yksilö, esimerkiksi yksittäinen oppilas tai opiskelija voisi arvioida omaa oppimistavoitettaan, hänen on tiedettävä, mikä se on. Esimerkiksi itsearvioinnin vaatiminen oppilaalta ilman, että hänen kanssaan on neuvoteltu tavoitteesta, on epärealistista. Yksilöiden ja yhteisön tavoitteiden muodostava kokonaisuus elää ja uudelleen suuntautuu jatkuvasti. Tämä edellyttää kaikkien yhteisön jäsenten huomioonottamista, se ikään kuin "pakottaa näkemään" ihmiset ympärillä ja näin myös tukee sosiaalisen verkoston muodostumista yhteisössä toimiville. Näin se voi toimia usein oppivan organisaation toteutumisen esteenä olevaa, ns. yksintekemisen kulttuuria murtavana elementtinä (ks. esim. Rajakaltio, 1994).

Voitaisiinkin sanoa, että oppivassa organisaatiossa toimijoiden on oltava tietoisia kokonaisuudesta ja toiminnan suunnasta. Heidän on pystyttävä reflektoimaan sitä. Tämä voisi olla oppivaa organisaatiota tukeva tulkinta itsearvioinnista. Jotta itsearviointi tukee oppimista, se on ymmärrettävä pikemminkin ajattelun strategiana, kuin arviointina sanan perinteisessä mielessä. Itsearvioinnin (tai itsereflektoinnin) tavoitteena on silloin omien, itselle merkittävien kysymysten löytäminen. Itsearviointi auttaa asettamaan tavoitteita herättämällä kysymään: mitä minun/meidän on opittava, jotta voisin/voisimme toimia mielekkäästi? Nämä kysymykset on esitettävä sekä itsen että yhteisön tasolla, yhdessä, ja niihin on palattava prosessin jokaisessa vaiheessa. Tämä merkitsee sitä, että tietoisesti etsitään osaamisen synenergiaetuja, luodaan oppimisympäristöä (Nikkanen \& Lyytinen, 1996). Kysymys on tavoiteorientaation melko radikaalista muuttamisesta suoritus- tai tuotosorientaatiosta oppimisorientaatioksi (performance-oriented / learning-oriented, Dweck \& Leggett, 1988).

Myös organisaatiosta puhuttaessa on olennaista paitsi analysoida oppimiskäsitys, jonka varassa sen oppimista tarkastellaan, myös selvi- tettävä, mikä on organisaatiossa itsessään vallitseva käsitys toimintansa muutoksesta. Esimerkiksi mitä tarkoittaa se, että organisaatiomme on "kehittynyt". Mikäli kehittyminen ja oppiminen tulkitaan siten, että jokaisen työntekijän on tauotta kurssitettava itseään ja omaksuttava jatkuvasti uusia käsitteitä, vaikka ne jäävät tyhjiksi, päädytään lopulta jaksamisen ongelmiin. Tällöin elinikäisestä oppimisesta tulee elinkautista suoriutumista. Voidaan kärjistäen väittää, että tällaisesta organisaation toimintamallista muotoutuu helposti lyhytkursseja suurkuluttava oravanpyörä. Tällaisessa organisaatiossa toimivat yksilöt kokevat itsensä helposti enemminkin suorittajiksi kuin oppijoiksi. Runsas määrä kehittämisprojekteja ja uudistuksia ei välttämättä kerro organisaation oppimisesta, vaan tietynlaisesta, ongelmallisestakin toimintakulttuurista. Kosunen ja Mikkola viittaavat tähän puhuessaan Kasvatus -lehden (2001) artikkelissaan "projektista toiseen elämisen" mukanaan tuomista ongelmista. Kehittämistyö tarkoittaa useimmissa organisaatioissa uuden lisäämistä vanhan päälle ja näin myös työn määrällistä lisääntymistä. Kehittäminen voitaisiin nähdä mahdollisuuteena laadullisesti uudelleen jäsentää oma työ, mutta paradoksaalisti usein ajanpuute estää tämän. Kiire on todellisen oppimisen este.

Toisaalta jos kehittyminen ja elinikäinen oppiminen tulkitaan näkemykseksi koko ihmisen elämänprosessiin, se näyttäytyy hyvinkin toisenlaisessa valossa. Kehittämistyö ei tällöin ole erillinen hanke, vaan itse asiassa ihmiselle luonteva tapa pyrkiä toimimaan mielekkäästi muuttuvissa olosuhteissa. Ihmisen ei myöskään tarvitse mennä kurssille oppiakseen, vaikka totta on, että usein ympäristön varioiminen, esimerkiksi työpaikalta koulutukseen lähteminen jo sinänsä parantaa oppimisen ehtoja: Valikoiva tarkkaavaisuus suuntautuu eri ympäristöissä eri asioihin, aktivaatiotason kohoaminen ja uudet vuorovaikutuskontekstit mahdollistavat oppimiskokemuksen, joka arkikielellä ilmaistaan usein vaikkapa "uuden katsantokannan aukeamisena". Tämä saattaa tuoda esiin esimerkiksi syvällistä ymmärrystä omasta työstä ja ns. hiljaisesta tiedosta (esim.hiljaisesta tiedosta ks. esim. Nonaka, 1995). Valitettavan usein kuitenkin myös kurssilla saatu oivallus jää hiljaiseksi, jos organisaatiolla ei ole välineitä ja toimintatapoja ymmärryksen jakamiseen. Oppivan organisaation merkki voisi olla vaikkapa sovitut käytännöt sille, miten organisaatio "lähettää" 
edustajansa oppimaan organisaation ulkopuolelle ja miten ottaa hänet jälleen vastaan.

Pragmatistisen konstruktivismin oppimiskäsityksen mukaisesti organisaation oppiminen, kuten oppiminen muutenkin, edellyttää, että oppijalle on herännyt kysymyksiä oman toimintansa tai ajattelunsa suhteen. Näiden kysymysten täytyy olla omaksi koettuja, oppijalle todellisia. Kurssin tai koulutuksen sisällöstä menee usein suurin osa sivu suun siksi, ettei koulutettavalla ole omaa tai "juuri meidän koulussa herännyttä kysymystä" liittyen aiheeseen. Ns. työssäoppimisen tehokkuus perustuu juuri sille, että siinä pyritään vastaamaan syvällisellä tavalla omiksi koettuihin kysymyksiin autenttisessa kontekstissa. Tällöin oppimisympäristön muodostaa organisaation toimintakulttuuri. Työssäoppimisen, kuten oppimisen edellytyksenä yleensä, on oppimista mahdollistava toimintakulttuuri. Se, että työyhteisön, kuten usein opettajanhuoneen arkea leimaa sirpaleisuus ja lyhytjännitteisyys sekä riskien välttäminen, ei mahdollista vastuuta kokonaisuudesta, sitoutumista tai turvallista ilmapiiriä eikä näin myöskään aitojen kysymysten heräämistä (esim. Rajakaltio, 1994; Rauste-von Wright et al. 2003).

\section{ORGANISAATION TRANSFER}

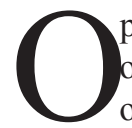

ppimisen keskeisimpiä kysymyksiä on se, onko sillä transferia, siirtovaikutusta eli onko yhdessä tilanteessa opittu "käytössä" muissa tilanteissa. Tätä näkökulmaa on vaikea ohittaa myöskään, kun tarkastelemme oppivan organisaation käsitettä nimenomaan oppimisen kannalta. Yksilöpsykologiasta johdettujen käsitteiden soveltaminen yhteisöön ei ole yksinkertaista. Usein organisaatiotasolle siirryttäessä päädytään määrittelemään ulkoista toimintaa leimaavia piirteitä tai erilaisia toimintamalleja. Jos transfer ymmärretään yhteisötasolla esimerkiksi erilaisina toimintaa kehittävinä (sinänsä merkittävinä) hankkeina, kadotetaan helposti itse transferprosessi.

Kiinnostavan näkökulman organisaatiotason oppimiseen tarjoaa toimintajärjestelmien tutkimukseen keskittyvä kehittävän siirtovaikutuksen teoria. Tällöin transfer määritellään oppilaitoksen ja työelämän rajoilla neuvotellen rakentuviksi uusiksi toimintamalleiksi, joissa syntyy uusia käsitteitä ja joissa nämä käsitteet hyödynnetään uuden ratkaisun tai toimintavan välineenä (ks. esim. Engeström, 2001). Tällaisten prosessien tuloksena syntyy käytännön muutoksia toiminnassa, ja niiden tukeminen ja analysointi on epäilemättä hyvin olennaista organisaation oppimisessa. Väitämme kuitenkin, ettei tämä riitä transferin määrittelyksi. Oppimisen transferia on inhimillisenä prosessina tapahduttava jo ennen yhteistoiminnallisesti luotuja uusia toimintoja. Transferprosessin on käynnistyttävä, jotta yhteisö voi yleensä havaita toiminnassaan jotain muuttamista, määritellä muutoksen suuntaa ja näin haluta kehittää sitä (ks. esim. Soini, 1999).

Transfer ei ole löydettävissä tuloksena syntyneessä uudessa toimintatavassa, vaan siihen johtaneessa, toimintaan osallistuvien yksilöiden prosesseissa. Mielenkiintoista onkin kysyä, millaisin ehdoin yksilöissä ja yhteisöissä käynnistyy toiminnallisia ja ajattelun prosesseja, joissa on mahdollista tiedostaa ja kyseenalaistaa olemassa olevaa ja esittää omia kysymyksiä? Kiinnostavaa on myös pohtia, millaisia valmiuksia edellyttää tällaisen aktiivisen transferprosessin ohjaaminen esimerkiksi koulutusorganisaation johdolta.

Arkemme hyvin opituissa rutiineissa omien kysymysten herääminen vaatii pysähtymistä. Pysähtymisen saattaa aiheuttaa oman toimintamme ajautuminen "kriisiin", kun aiemmin käytetty toiminnan strategia ei enää toimikaan. Tällöin ympäristöltä saamamme palaute ei vastaa odotuksiamme ja syntyy paikka oman toiminnan tarkistamiseen. Ongelmana tämän kaltaisissa pysähtymisissä on se, että olemme kulttuurisesti oppineet tulkitsemaan ne epäonnistumisiksi ja kielteisiksi viesteiksi meistä itsestämme. Tällöin itseämme suojataksemme usein vältämme tilanteita, joissa olisi mahdollista saada konfrontoivaa palautetta. Jos tällaiseen tilanteeseen joudumme, pyrimme suojaamaan itseämme esimerkiksi selittämällä pois toiminnastamme annettua palautetta. Kouluttajan, kasvattajan ja johtajan vaikeimpia kysymyksiä on, miten saada aikaan niin turvallinen, hyväntahtoinen ja oppimiselle avoin ilmapiiri, että konfrontaatio johtaa uusien kysymysten syntymiseen puolustautumisen sijasta? Toisin sanoen miten luoda kulttuuria, joka sallisi ihmettelyn kaikille siihen osallistuville? Pysähtymisen paikkojen luominen on osoittautunut niiden meidän, kuin monien muiden koulutusorganisaatioiden tutkijoiden tutkimuksissa keskeiseksi ja samaan aikaan haasteellisimmaksi tehtäväksi koulutusorganisaation oppimaan oppimisessa. Koska kiire on paitsi koulutusorganisaatioiden(kin) 
todellisuutta, myös kulttuurisesti erittäin hyväksytty selitys, pysähtymisen paikkojen luominen vaatisi paikoin radikaalejakin uudelleen priorisointeja.

Hyväntahtoisen, ihmettelyn sallivan ja siihen pyrkivän ilmapiirin, toisin sanoen kyseenalaistamisen kulttuurin ('culture of thought', Costa, 1992) kehittyminen vaatii työtä. Se vaatii myös organisaation olemassa olevan toimintakulttuurin tiedostamista eli itsearviointia siinä mielessä, kuin se edellä määriteltiin. Tämä puolestaan edellyttää metakognitiivisia valmiuksia sekä yksilön että yhteisön tasolla. Mutta mitä lopulta tarkoittaa metakognitiivisen tiedon lisääminen? Kuten nykyisen oppimista koskevan ymmärryksen valossa tiedämme, 'tiedon lisääminen' esimerkiksi koulutuksessa on ongelmallista. Vaikka tieto lisääntyisi, yliopisto-opiskelijat vaikkapa lukisivat paljon metakognitioon liittyvää tutkimuskirjallisuutta, se ei välttämättä lisää heidän metakognitiivisia valmiuksiaan. Kun viemme asian koko yhteisön tasolle, joudumme myös kysymään, onko olemassa ryhmien tai organisaation metakognitiivisia valmiuksia ja mitä ne ovat?

Jos siis oletamme, että oppivia organisaatiota on olemassa, meidän on myös oletettava, että on organisaatioita, jotka hyödyntävät aktiivisesti oppimistaan uusissa tilanteissa. Oppivaa organisaatiota tarkasteltaessa transfer voi muotoutua esimerkiksi kysymykseksi: näkyykö se, mitä ymmärsimme eilen, meidän toiminnassamme tänään? Jos näkyy niin miten? Jos ei niin miksi ei? Tämä tarkoittaa, että organisaatio ei toista toimimattomaksi osoittautuneita toimintamalleja, vaan testaa toimintamallejaan pohtien, miksi ne eivät toimi, ja käynnistävät näin reflektiivisiä oppimisprosesseja. Argyris (1990) on viitannut tähän puhuessaan yksisilmukkaisesta ja kaksisilmukkaisesta oppimisesta. Yksisilmukkaisessa oppimisessa organisaatio etsii ongelmia tai virheitä, jotka voitaisiin korjata. Kaksisilmukkainen oppiminen viittaa siihen, että organisaatiossa tarkastellaan, kyseenalaistetaan ja muutetaan toimintojen taustalla olevia ja niitä määrääviä tekijöitä, jolloin tämä reflektiivinen toiminta muuttaa myös varsinaisia toimintoja. Mutta ajatusta on jatkettu vielä vähän pidemmälle puhuttaessa organisaation oppimaan oppimisesta, tai Argyrisin ja kumppaneiden termein deutero-oppimisesta. Tällöin organisaation oppiminen on itseohjautuvaa, kehittäminen ja oppiminen on osa työtä (Agryris \& Schön 1978; Argyris, 1990).
Reflektiivistä omien toimintojen perusteiden pohtimista ja itseohjautuvuuteen pyrkimistä voisi kutsua myös organisaation transferiksi. Se edellyttää metakognitiivisia valmiuksia sekä yksilön että ryhmän ja yhteisön tasolla. Voidaan puhua myös muutoksen hallinnan valmiuksista. Samoin kuin opitun transfer yleensä, myös organisaation toimintakulttuurin muutos ja muutoksen hallinta ovat haasteellisia. Niiden on joskus väitetty olevan miltei mahdottomia. Näin pessimistisiin arvioihin ei kuitenkaan ole aihetta. Mitä paremmin pyrimme ja opimme ymmärtämään näitä muutosprosesseja, sitä todennäköisemmin pystymme myös arvioimaan ja ohjaamaan tietoisesti ja tavoitteellisesti koulutusorganisaation kehittymistä oppivaksi organisaatioksi.

\section{LOPUKSI}

Olemme pohtineet oppivan organisaation merkitystä nimenomaan koulutusorganisaatioihin peilattuna. Esitämme, että juuri koulutusorganisaatioiden tulisi toimia tässä oppimisen asiantuntijoina ja kehityksen suunnannäyttäjinä. Monet organisaatioita ja työyhteisöjä kouluttavat sanovat kuitenkin huomanneensa saman kuin tämän artikkelin kirjoittajat: on helpompi saada oppivan organisaation ajatuksia toimimaan esimerkiksi teollisuusyrityksessä kuin koulussa. Mahdolliset ongelmat koulutusorganisaatioiden pyrkiessä kehittymään oppiviksi voivat johtua niissä elävistä, hyvin syvään juurtuneista käsityksistä liittyen oppimiseen. Koulutusorganisaation ovat instituutioita, joissa oppiminen on totuttu operationalisoimaan ja formalisoimaan ja joissa toimivat ihmiset tuntevat voimakasta ammattiylpeyttä esimerkiksi omasta opettamistyylistään. Ja hyvä näin. Valitettavasti tämä sinänsä terve omanarvontunto ja asiantuntijuus voi estää uusien toimintatapojen tuloa. Ja vaatimus oman työn ytimen uudelleen jäsentämisestä voi aiheuttaa puolustautumisreaktion.

Toinen ongelma oppivan organisaation todeksi elämisessä koulutusorganisaatioissa lienee se, että taloudellisen tehokkuuden nostaminen on aina selkeämpi peruste ja siihen löytyy johdon tahtoa enemmän kuin näkymättömämmän inhimillisen kasvun tukemiseen. Näin ollen yhtenä selityksenä oppivan organisaation toteutumisen ongelmille koulutusorganisaatioissa voidaan nähdä myös arviointijärjestelmä, jonka kriteerit ovat usein yhä pitkälti määrällisiä, tuotosta, mää- 
rää ja muistamista painottavia. Koulujen välisessä arvioinnissa tämä näyttäytyy tuotettujen tutkintojen määrään perustuvana rahanjakomallina, kun taas oppilas arvioinnissa tämä merkitsee tuotoksiin ja suoritteisiin perustuvaa arviointia. Oppiva organisaatio edellyttääkin myös arviointijärjestelmän muutosta, jossa määrällisten seikkojen sijasta painotetaan laadullisia kriteereitä, esimerkiksi jatkuvaa tiedon rakentelua, oppijoiden käsityksissä ja toimintatavoissa tapahtuvia laadullisia muutoksia sekä oppimisprosessiin painottavaa arviointia (Pyhältö, 2003). Eittämättä koulutusorganisaatio, jonka toimijat pyrkivät tietoisesti yhdessä konstruoidun tavoitteen suunnassa luomaan mielekkäitä oppimisympäristöjä itselleen ja muille, on kilpailukykyinen myös määrällisiä arvioinnin kriteereitä käytettäessä.

Kysyimme artikkelin alussa, onko oppivan organisaation käsitteellä mahdollisuuksia toimia kehittämisen välineenä? Se, kelpaako oppivan organisaation käsite (ja siihen liittyvä termistö) organisaation toimintaa jäsentäväksi työkaluksi, riippuu epäilemättä työkalun käyttäjistä. Mikäli yhteisössä ollaan aidosti kiinnostuneita oppimisesta ja oman toiminnan perusteiden pohtimisesta, oppivan organisaation idea tarjoaa pohdinnalle lähtökohdan ja yhteisen kielen. Oppivan organisaation ideaan sisältyy myös voimakas vastuu kokonaisuudesta. Tämä edellyttää, että yhteisössä ollaan kiinnostuneita kaikkien organisaation jäsenten oppimisesta ja kehittymisestä, tällöin ihmettely ja kyseenalaistaminen ja niiden ilmaiseminen muodostuvat yleisesti hyväksytyiksi osiksi organisaation toimintaa. Oppivassa organisaatiossa jokaisella on näin ollen oikeus ja velvollisuus luoda yhteistä oppimisympäristöä. Tämä tarkoittaa esimerkiksi sitä, että organisaatiossa ei ole vain velvollisuutta ottaa vastaan palautetta, vaan myös oikeus saada sitä.

\section{VIITE}

Artikkeli perustuu kaksivuotiselle yhtenäinen peruskoulututkimus- ja kehittämishankkeelle, joka toteutettiin vuosina 2000-2001 yhteistyössä kahden helsinkiläisen yhtenäisen peruskoulun kanssa. Hanke on kokonaisuudessaan raportoitu Koulun eksperttiys -Tutkimus yhtenäisen peruskoulun toteutumisen ehdoista -kirjana Helsingin kaupungin opetusviraston julkaisusarjassa A1:2003. Tässä artikkelissa hankkeessa tehtyjä havaintoja hyödynnetään tarkasteltaessa oppivan orga- nisaation käsitettä koulutusorganisaation kehittämisen välineenä.

\section{LÄHTEET}

Agryris, C. (1990) Overcoming organizational defenses. Facilitating organizational learning. USA: Allyn \& Bacon.

Argyris, C. \& Schön, D. (1978) Organizational learning: A theory of action perspective. USA: Addison-Wesley Publishing Company.

Cobb, P. (1994) Where is the mind? Constructivist and sociocultural perspectives on mathematical development. Educational Reseacher, 23, 13-20.

Cobb, P. \& Bowers, J. (1999) Cognitive and situated learning perspectives in theory and practice. Educational Researcher, 28, 4-15.

Costa, A.L. (1992) An environment for thinking. In Collins, C. \& Mangieri, J.N. (Eds.), Teaching thinking: an agenda for the $21^{\text {st }}$ century. USA: Lawrence Erlbaum.

Dweck, C.S. \& Leggett, E.L. (1988) A sosiocognitive approach to motivation and personality. Psychological Review, 95, 256-273.

Engeström, Y. (2001) Kehittävä siirtovaikutus: mitä ja miksi? Teoksessa Tuomi-Gröhn, T. \& Engeström, Y. (toim.) Koulun ja työn rajavyöhykkeillä. Uusia työssä oppimisen mahdollisuuksia. Yliopistopaino.

European commission 1996, White paper on education and training. Teaching and learning. Towards the learning society. Commission of the European Union, Brussels.

Greeno J.G. (1997) Response: On claims that answer the wrong questions. Educational Researcher, 26, 5-17.

Kosunen, T. \& Mikkola, A. (2001) Opettajankoulutuksen tavoitteet ja todellisuus. Kasvatus, 5, 478-492.

Moilanen, R. (1996) Oppiva organisaatiotausta ja käsitteistö. Jyväskylän yliopisto, Taloustieteen laitos, julkaisuja n:o 100. Jyväskylä.

Nikkanen, P. \& Lyytinen, H.K. (1996) Oppiva koulu ja itsearviointi. Koulutuksen tutkimuslaitos. Jyväskylän yliopisto.

Nonaka, I. (1995) The knowledge-creating company: How Japanese companies create the 
dynamics of innovation. New York: Oxford University Press.

Pedler, M., Burgoyne, J. \& Boydell, T. (1991) The learning company. A strategy for sustainable development. USA, Berkshire: McGraw-Hill.

Pyhältö, K. (painossa) Pragmatistiskonstruktivistinen näkökulma opettajuuteen: Uusi opettajuus? Väitöskirja. Opettajankoulutuslaitos, Helsingin yliopisto.

Rajakaltio, H. (1994) Kulttuurimuutos kehittämistyössä. Teoksessa Kasvio, A., Nakari, R., Kalliola, S., Kuula. A., Pesonen, I. Rajakaltio, H. \& Syvänen S. Uudistumisen voimavarat. Tutkimus kunnallisen palvelutuotannon tuloksellisuuden ja työelämän laadun kehittämisestä. T-sarjan julkaisuja 14, Tampereen yliopisto: Yhteiskuntatieteiden tutkimuslaitos.

Rasku-Puttonen, H. \& Eteläpelto, A. (1999) Projektioppimisen haasteet ja mahdollisuudet. Teoksessa Oppiminen ja asiantuntijuus. Työelämän ja koulutuksen näkökulmia. WSOY.

Rauste-von Wright, M., Soini, T., Pyhältö, K., Eerola, S., Pyhälä, S. \& Rämä, I. (2003) Koulun eksperttiys. Tutkimus yhtenäisen peruskoulun toteutumisen ehdoista. Helsingin kaupungin opetusviraston julkaisusarja A1.

Rauste-von Wright, M., von Wright, J. \& Soini, T. (9. uudistettu painos, 2003) Oppiminen ja koulutus. WSOY.
Rauste-von Wright, M. (1997) Opettaja tienhaarassa. Konstruktivismia käytännössä. WSOY.

Resnick, L.B. \& Williams Hall, M. (1998) Learning Organizations for Sustainable Education Reform. Daedalus, 127, 89-118.

Resnick, L.B. (1991) Shared cognition: Thinking as social practice. In Resnick, L.B., Levine, J.M. \& Teasley, S.D. (toim.), Perspectives on socially shared cognition. American Psychological Association.

Salomon, G. (1997) Novel constructivist learning environment and novel technologies: some issues to be concerned with. Invited key note address at the 7th European Conference for research on learning and instruction, Athens, August 1997.

Sarala, U. \& Sarala, A. (1996) Oppiva organisaatio: Oppimisen, laadun ja tuottavuuden yhdistäminen. Gaudeamus.

Senge, P. (1990) The fifth discipline. The art and practice of the learning organization. USA: Doubleday/Currency.

Soini, T. (1999) Preconditions for active transfer in learning processes. Commentationes Scientiarum Socialium 55. The Finnish society of sciences and letters.

Tynjälä, P. (1999) Oppiminen tiedon rakentamisena. Konstruktivistisen oppimiskäsityksen perusteita. Kirjayhtymä.

Artikkeli saapui toimitukseen 25.2.2003. Se hyväksyttiin julkaistavaksi 5.11.2003. 